\title{
DOXA - REVISTA BRASILEIRA DE PSICOLOGIA E EDUCAÇÃO
}

v. 19, n. 2, jul./dez. 2017

\section{EDITORIAL}

Com satisfação publicamos o v. 19, n. 2, jul./dez. da DOXA - Revista Brasileira de Psicologia e Educação, que apresenta, além dos artigos gerais iniciais, uma sessão temática denominada Dossiê que, neste número, traz a temática Infância e Práticas Educativas.

O Editor 